\title{
Scholars and Literati at the University of Gießen (1607-1800)
}

\author{
David de la Croix \\ Robert Stelter \\ IRES/LIDAM, UCLouvain \\ University of Basel
}

This note is a summary description of the set of scholars and literati who taught at the University of Gießen from its inception in 1607 to the eve of the Industrial Revolution (1800).

\section{The UnIVERsity}

The University of Gießen - the Ludoviciana - is a typical example for a small state university in the seventeenth and eighteenth centuries. Landgrave Ludwig V. of Hesse-Darmstadt initiated the foundation of a Lutheran university in Gießen as there was a need to train Lutheran pastors and civil servants, when the nearby University of Marburg became Calvinist. Soon after teaching started in October 1607, the Thirty Years War erupted, and the Ludoviciana closed temporarily. It was restored in Gießen in 1650 with the four usual faculties: Theology, Law, Medicine, and Arts. Limited financial resources restricted reform efforts in the eighteenth century so that there was little change until the very end of the century. Still, notably a faculty of economics existed from 1777-1785. Its tradition continued in the faculties of medicine and philosophy.

\section{SOURCES}

The chronicle of the University of Gießen has been published in two books: (Haupt and Lehnert 1907) includes the history of the Ludoviciana between 1607 and 1907, while (Rehmann 1957) focuses on the following 50 years. As we are interested in the pre-1800 period, we rely on the book by (Haupt and Lehnert 1907). In addition to an overview of the most important events, the second part of the book lists the scholars and literati of the university in alphabetical order. We only added very few cases from other sources to the almost 300 names.

\section{SOME STATISTICS}

Table 1 displays some descriptive statistics for the 298 scholars and literati we link to the University of Gießen. For 254 of them, the birth year has been documented. The mean age at appointment is around 31.2 years and is highest around 1700. Surprisingly, we observe a slightly decreasing mean age of death from around 60 to less than 59 years. For more than $95 \%$, the birth place is known, with a median distance of around $150 \mathrm{~km}$ to the university. The distance is highest in the period when the university was established, which attests to the attractiveness of the young university. $85 \%$ of the scholars active in Gießen left a footprint in the catalogues of the libraries of the world, Worldcat, either by having published some work, or by having been the subject of published books and articles. The share of scholars with a Wikipedia page is $40 \%$.

\section{FIELDS}

Figure 1 shows the relative importance of fields, broadly defined. The distribution of scholars across the fields of sciences at the University of Gießen reflects the wide range of scientific activities. Still, we observe a dominance of the fields linked to the four traditional faculties that are humanities, law, 
medicine, and theology. In addition to the well-known theologians, the natural sciences were well represented at the university.

\begin{tabular}{|c|c|c|c|c|c|c|}
\hline \multicolumn{2}{|c|}{ Period } & nb. & $\%$ birth year & mean age & mean age & exp. age \\
\hline Start & End & obs & known & at nomin. & at death & at death \\
\hline 1527 & 1617 & 43 & 69.8 & 30.9 & 60.1 & 60.4 \\
\hline 1618 & 1685 & 72 & 90.3 & 30.5 & 60.9 & 61.3 \\
\hline 1686 & 1733 & 81 & 85.2 & 32.3 & 58.6 & 57.6 \\
\hline 1734 & 1800 & 102 & 88.2 & 31 & 58.5 & 60.8 \\
\hline 1000 & 1800 & 298 & $\overline{8} \overline{5} . \overline{2}$ & $3 \overline{1} . \overline{2}$ & $\overline{5} \overline{9} . \overline{3}$ & 60.1 \\
\hline & & & $\begin{array}{c}\% \text { birth place } \\
\text { known }\end{array}$ & $\begin{array}{l}\text { median distance } \\
\text { birth-institution }\end{array}$ & $\begin{array}{c}\% \text { with } \\
\text { Wikipedia }\end{array}$ & $\begin{array}{c}\text { \% with } \\
\text { Worldcat }\end{array}$ \\
\hline 1527 & 1617 & & 97.7 & 184 & 44.2 & 86 \\
\hline 1618 & 1685 & & 100 & 138 & 43.1 & 84.7 \\
\hline 1686 & 1733 & & 90.1 & 160 & 34.6 & 85.2 \\
\hline 1734 & 1800 & & 95.1 & 145 & 40.2 & 87.3 \\
\hline 1000 & 1800 & & $\overline{9} \overline{5} . \overline{3}$ & $15 \overline{3}$ & $39 . \overline{9}$ & 85.9 \\
\hline
\end{tabular}

Table 1: Summary statistics by period

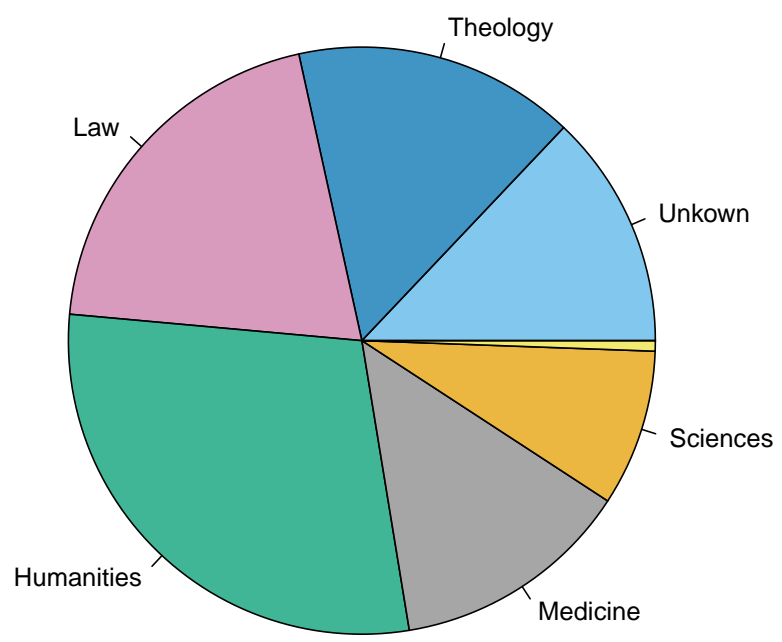

Figure 1: Broad fields at the University of Gießen 


\section{Place OF Birth}

Figure 2 displays the places of birth of all the scholars active at the Ludoviciana. We document the Germanic nature of the university.

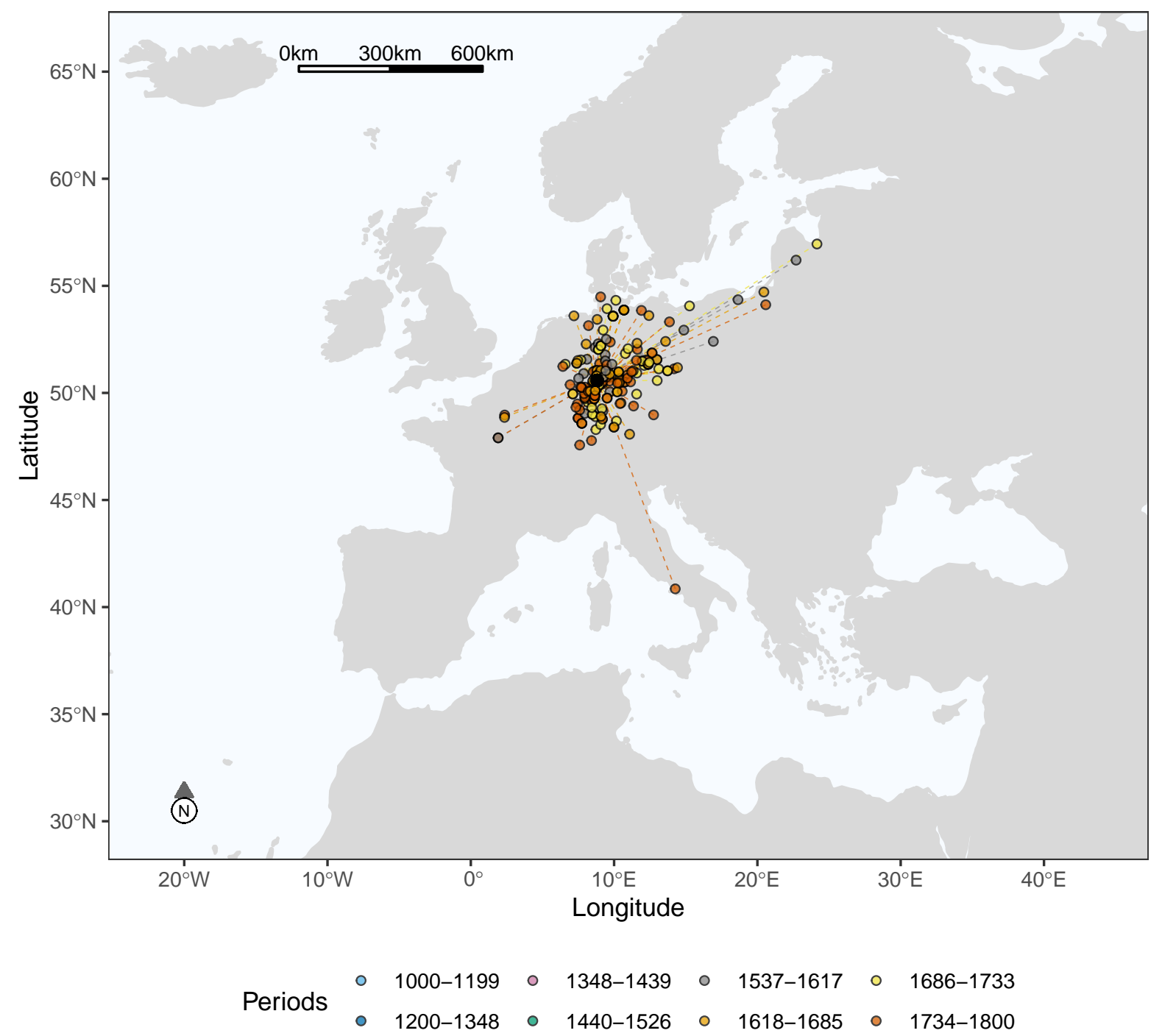

Figure 2: Places of birth of the scholars and literati at the University of Gießen

\section{HUMAN CAPITAL OF SCHOLARS AND LITERATI}

For each person in the database we compute a heuristic human capital index, identified by combining information from Worldcat and Wikipedia using a principal component analysis. We also compute the notability of the university at each date by averaging the human capital of the scholars active in Gießen 25 years before that date. Details are given in the Appendix. Figure 3 shows the names of all the scholars with a positive human capital index. The orange line plots the notability of the university.

The pattern is one of a good university over the period considered. When comparing this graph with the equivalent one for other universities, notice that the scale of the vertical axis may not be the same. Here, the range is $(0,8)$, while for Jena another German, Lutheran university, see De la Croix and Stelter $(2020)$, we have $(0,14)$ to accommodate several scholars with an index between 8 and 14. 


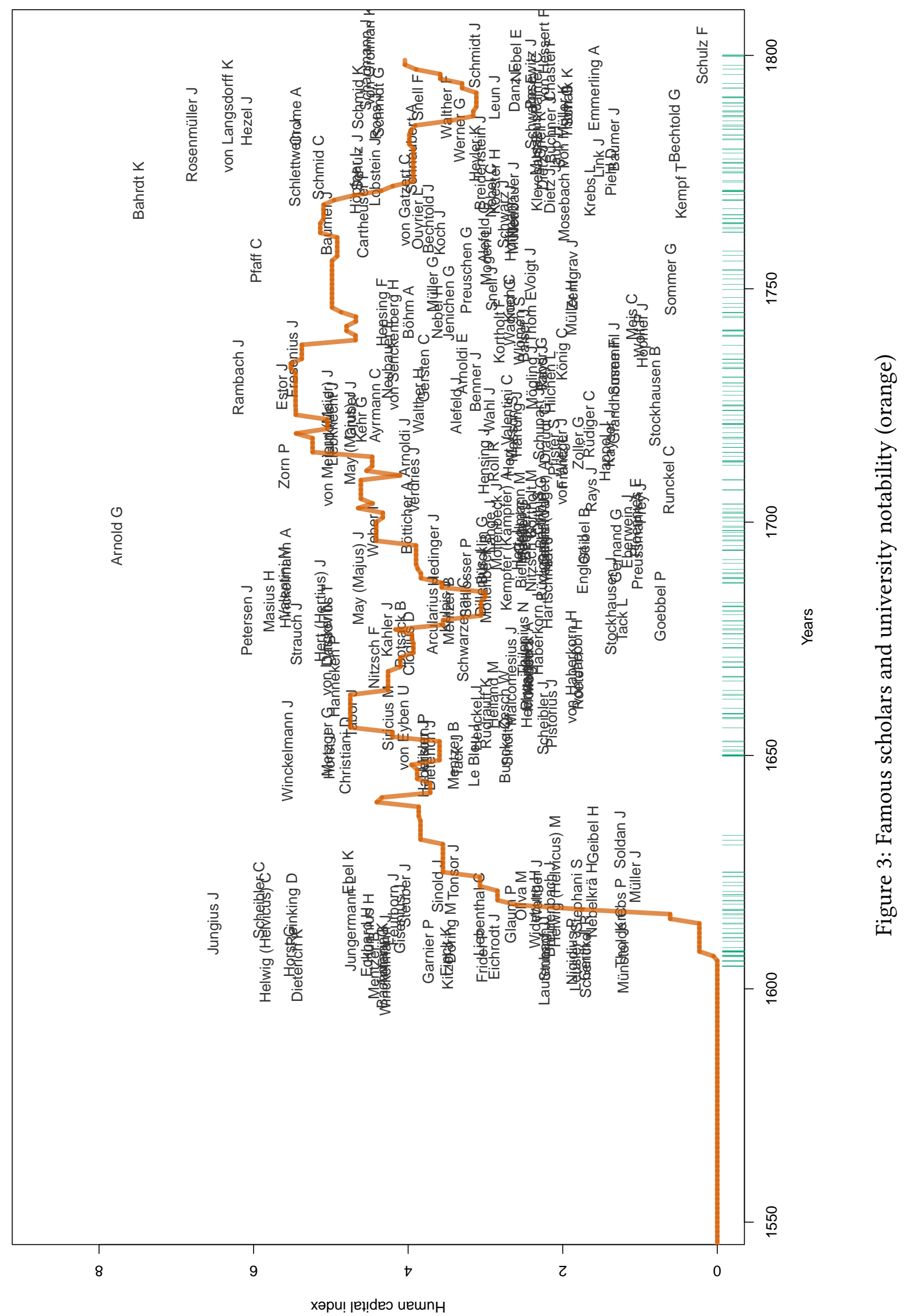




\section{TOP 5 PROFESSORS}

We now provide a brief overview of the five professors with the highest human capital index.

Gottfried Arnold (Annaberg 1666 - Perleberg 1714) was a theologian and a historian. His journey through life reflects drastic shifts. He studied at the Lutheran University of Wittenberg. His conversion to radical pietism characterized the next years and led to his appointment at the University of Gießen in 1697. Turning to radical spiritualism, he left the university in spring 1698. Finally, he turned to a less radical attitude, married and took a position as a clergyman. Even if his academic career was short, he is well-known for his contributions to pietism.

Karl Friedrich Bahrdt (Bischofswerda 1740 - Nietleben 1792) was a German enlightener and theologian who was involved in a variety of theological movements. He studied at Leipzig and received his doctoral degree from Erlangen. His professorships at Leipzig, Erfurt, and Gießen did not last long due to his dissolute lifestyle. He was then hired as a private lecturer at Halle, where he aimed to explain the miraculous passages of the Bible in a rational way. $\mathrm{He}$ established the Deutsche Union, a German secret society similar to the Illuminati and the Freemasons.

Johann Georg Rosenmüller (Ummerstadt 1736 - Leipzig 1815) was a German Protestant theologian. After studies in philosophy, philology, and theology at Altdorf, he was appointed as an ordinary professor at the universities of Erlangen, Gießen, and Leipzig. His history of Biblical interpretation is among his key scientific contributions.

Joachim Jungius (Lübeck 1587 - Hamburg 1657) was a mathematician, physicist, physician, and philosopher, who proved that a catenary curve is not a parabola. He studied at Rostock and since 1608 at the young Ludoviciana. The latter appointed him as a professor of mathematics one year later, at the age of 22. Later on, he was hired at the universities of Rostock and Helmstedt, and finally at the Gymnasium Academicum in Hamburg. In 1622, he founded the Societas ereunetica sive zetetica - the first scientific society north of the Alps.

Carl Christian von Langsdorf (Nauheim 1757 - Heidelberg 1834) studied law and mathematics at Göttingen and Gießen, where he also lectured in mathematics in the summer of 1781 . He interrupted his academic career for some years before he was appointed at Erlangen, Vilnius, and Heidelberg as a professor in mathematics and technology. Practical applications of technology were some of his strengths, as illustrated by the number of publications on technology and his contribution to the discovery of the salt spring in Baden. He was interested in theological questions and published on this topic as well.

\section{FAMILIES OF SCHOLARS}

We counted 14 father-son pairs among the professors at the University of Gießen. Figure 4 shows the genealogical tree of the Mentzer family, drawn from Geneanet, who contributed three professors in theology. The person at the root of this tree, Justus, was "Sodenmeister," which probably means he had a managing position at salt works. The first professor at the university, Balthasar I, has 1,079 publications on Worldcat, while his son has 134 , and his grandson 62 . This declining pattern might indicate some degree of favoritism in the appointments (De la Croix and Goñi 2020). The last Balthasar of the family, Balthasar V, was a pastor in Hattorf. 


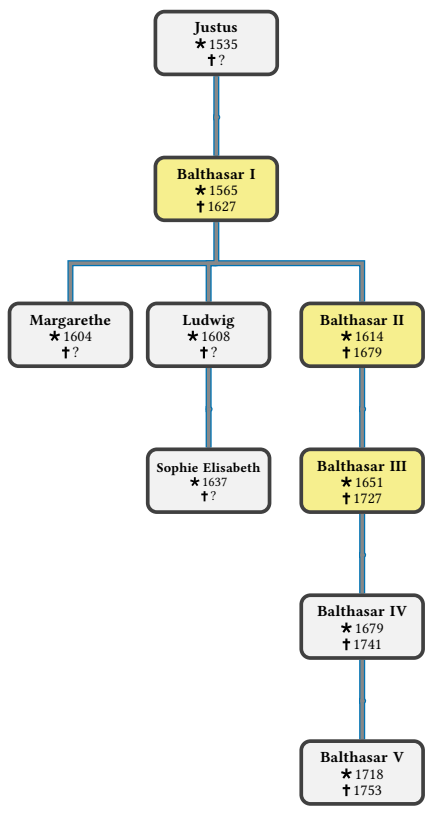

Figure 4: The Mentzer family. Professors at the University of Gießen in yellow squares

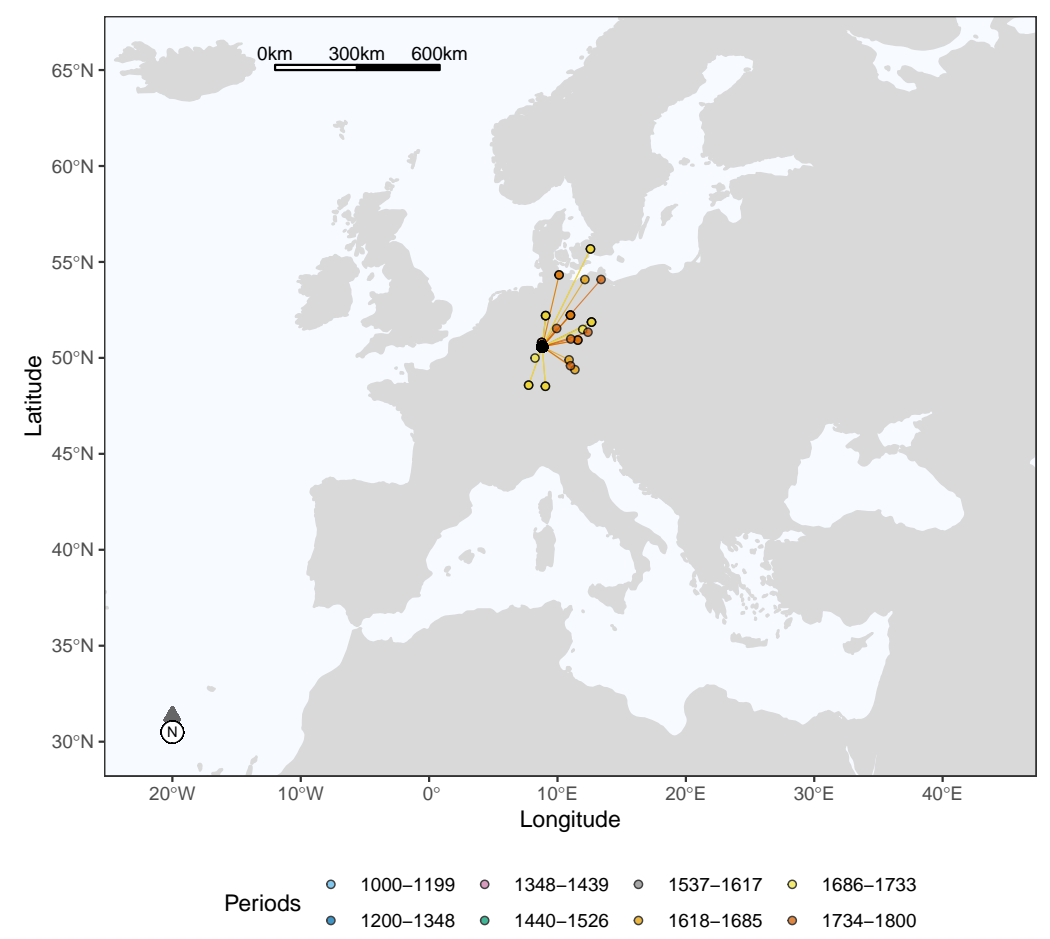

Figure 5: Links between the Ludoviciana and other universities through scholars' mobility, by period 


\section{UNIVERSITY NETWORK}

Here we assume that when a professor occupied a position at more than one university over his/her life, this established a link between those universities. The universities with which the Ludoviciana is linked are displayed in Figure 5. This picture complements what we saw before in terms of quality. The professors at Gießen moved in a local academic market, occupying positions at other Germanic universities, but not elsewhere. This lack of mobility might also be related to the strong Lutheran nature of the university.

\section{AnecDotes}

Initially, Gottfried Arnold considered his appointment as a professor at the University of Gießen without any effort as a sign from god. Yet with his conversion to radical spiritualism, this position was impossible to keep. He then considered his appointment as a mistake and left the university, a decision that caused a sensation.

In 1777, the economist Johann August Schlettwein (1731 -1802) moved from the University of Basel to the Ludoviciana to become a professor at the newly established economic faculty. He was appointed as the first dean of an economic faculty at a German university. Although his physiocratic disposition already led to disputes in opinions with the territorial lord, he kept the position until 1785. Then, a new conflict regarding his pro-imperial reading of the constitution led him to quit, which triggered the dissolution of the faculty (Gerteis 1990).

\section{APPENDIX}

The individual human capital index $q_{i}$ of an individual $i$ is given by:

$$
\begin{aligned}
q_{i}= & -1.76+0.43 \ln (\mathrm{nb} . \text { characters of the longest Wikipedia page }) \\
& +0.40 \ln (\mathrm{nb} . \text { wikipedia pages in different languages })+0.47 \ln (\text { nb. works in Worldcat }) \\
& +0.46 \ln (\text { nb. publication languages in Worldcat })+0.47 \ln (\mathrm{nb} \text {. library holdings in Worldcat })
\end{aligned}
$$

We assume that having no Wikipedia page is similar to having one page with a length of 60 characters and that having no Worldcat page is similar to having a page with one work in one language held by one library. The constant -1.76 normalizes $q_{i}$ at 0 when there is neither a Wikipedia page, nor a Worldcat page. The weights $(0.43,0.40$, etc) are obtained from the first principal component of the five indicators (De la Croix et al. 2020).

The notability $Q$ of a university aggregates the $q$ of the top 5 persons who were active in the preceding 25 years using the following formula:

$$
Q=\sqrt{\sum_{i=1}^{5} \frac{1}{5}\left(\frac{q_{i}}{s_{i}}\right)^{2}}
$$

where $s_{i}$ is the number of universities in which $i$ had an appointment.

\section{ACKNOWLEDGMENTS}

This project has received funding from the European Research Council (ERC) under the European Union's Horizon 2020 research and innovation programme under grant agreement No 883033 "Did elite human capital trigger the rise of the West? Insights from a new database of European scholars." Robert Stelter acknowledges financial support from the Max Geldner Foundation. 


\section{REFERENCES}

De la Croix, David, Frédéric Docquier, Alice Fabre, and Robert Stelter. 2020. "The Academic Market and the Rise of Universities in Medieval and Early Modern Europe (1000-1800).” CEPR Discussion Paper 14509.

De la Croix, David, and Marc Goñi. 2020. "Nepotism vs. Intergenerational Transmission of Human Capital in Academia (1088-1800).” CEPR Discussion Paper No. 15159.

De la Croix, David, and Robert Stelter. 2020. "Scholars and Literati at the University of Jena (15581800).” Repertorium Eruditorum totius Europae 1:25-32.

Gerteis, Klaus. 1990. “Johann August Schlettwein (1731-1802).” Aufklärung 4 (1): 105-107.

Haupt, Herman, and Georg Lehnert. 1907. Chronik der Universität Gießen von 1607-1907. Gießen: Universitätsbibliothek.

Rehmann, Wilhelm. 1957. Chronik der Ludwigs-Universität Gießen 1907-1945 und der Fustus LiebigHochschule Gießen 1946-1957. Gießen: Universitätsbibliothek. 